\title{
‘Keep Calm and Carry On’: EU Legal Developments in
}

\section{6}

\section{JOHN COTTER}

University of Wolverhampton Law School

\section{Introduction}

For reasons not requiring much exposition, 2016 was an annus horribilis for the EU. A review of the EU judiciary's 2016 activity reveals that the constituent courts of the Court of Justice of the EU (CJEU), the Court of Justice and the General Court, do not have the luxury of existing above the tumult in splendid isolation. In a year in which old and new problems for the EU dominated the headlines, these challenges found shape in justiciable controversies. In total, the Court of Justice and the General Court delivered 844 judgments in 2016, with the Grand Chamber, the Court of Justice's upper tier, responsible for 42 judgments, representing a reduction in the number of judgments compared to previous years. ${ }^{1}$ The growth in the CJEU's personnel continued, with an 11th Advocate-General, Evgeni Tanchev (a Bulgarian), taking his place on the Court of Justice, and 22 General Court Judges appointed throughout the year, bringing the total number at the General Court to $44 .{ }^{2} 2016$ also saw the abolition of

\footnotetext{
${ }^{1}$ Statistics from InfoCuria. Available online at: http://curia.europa.eu/juris/recherche.jsf?language=en; accessed 24 March 2017. However, in terms of case completion, the CJEU's overall activity increased in 2016. CJEU, Press Release No 17/17, Luxembourg, 17 February 2017. Available online at: http://curia.europa.eu/jcms/upload/docs/application/pdf/2017-02/cp170017en.pdf, accessed 24 March 2017.

${ }^{2}$ Article 48 of Protocol No. 3 on the Statute of the CJEU provides that the General Court shall consist of 47 Judges from 1 September 2016 and two Judges per member state from 1 September 2019.
} 
the Civil Service Tribunal, a specialized court that had adjudicated disputes between the EU and its civil servants: its competences have been returned to the General Court. ${ }^{3}$

This contribution seeks to analyze the year's most significant judgments in terms of impact on European integration, with a particular focus on the approaches adopted by the EU judiciary in response to challenges facing the EU. In accordance with convention, this contribution concentrates on the work of the Grand Chamber. In order to ensure continuity with previous years, this contribution confines itself to three subject areas. Section I provides a brief overview of the Grand Chamber's activity in the area of eurozone crisis management, before providing a more in-depth analysis of its judgment in Ledra Advertising. ${ }^{4}$ Section II examines developments in EU data protection law, particularly the ruling in Tele2 Sverige. ${ }^{5}$ Section III discusses the Court's development of EU citizenship rights in 2016.

\section{Eurozone Crisis Management}

In recent years, the Court of Justice has been called upon to rule on the general compatibility of the novel eurozone crisis-management mechanisms developed by EU institutions and the euro area states with the EU Treaties. In 2012, in Pringle ${ }^{6}$ (Amtenbrink, 2013, pp. 142-145), the full Court ruled that the euro area states could conclude and ratify the European Stability Mechanism (ESM) Treaty and, the Grand Chamber, in 2015, in Gauweiler ${ }^{7}$ (Horsley, 2016,

\footnotetext{
${ }^{3}$ Article 50a of Protocol No. 3.

${ }^{4}$ Ledra Advertising (Joined Cases C-8/15 P to C-10/15 P) ECLI:EU:C:2016:701.

${ }^{5}$ Tele2 Sverige AB and Watson (Joined Cases C-203/15 and C-698/15) ECLI:EU:C:2016:970.

${ }^{6}$ Pringle (Case C-370/12) ECLI:EU:C:2012:756.

${ }^{7}$ Gauweiler (Case C-62/14) ECLI:EU:C:2015:400. On 21 June 2016, the German Federal Constitutional Court (BVerfG) ruled that the OMT (Outright Monetary Transactions) programme, if interpreted in accordance with the Grand Chamber's judgment, does not exceed the ECB's competences or offend against the Bundestag's budgetary competences (2 BvR 2728/13, 2 BvR 2729/13, 2 BvR 2730/13, 2 BvR 2731/13, 2 BvE 13/13).
} 
pp. 118-122), upheld the European Central Bank's (ECB) Outright Monetary Transfers (OMT) programme. There was another such case in 2016, with the Court in Kotnik upholding the validity of the Commission's 2013 Banking Communication, ${ }^{9}$ which provides guidance to member states as to when state aid may be utilized to support banks for the purpose of ensuring financial stability. With challenges to the generality of these mechanisms exhausted, the contested ground has shifted to their operation, particularly where individual rights are affected, a phenomenon observable in 2016. In Ledra Advertising, the Court was required to clarify the Commission's legal obligations in its activities under the ESM Treaty. On the same day, the Grand Chamber in Mallis, ${ }^{10}$ which like Ledra Advertising involved circumstances surrounding ESM financial assistance to Cyprus, held that a Eurogroup statement welcoming an agreement between the ESM and Cyprus on conditionality for financial assistance was not amenable to an annulment action under Article 263 of the Treaty on the Functioning of the EU (TFEU). In Dowling, ${ }^{11}$ the Grand Chamber was confronted with what was essentially an indirect challenge to a Memorandum of Understanding (MoU) concluded between the Commission and ECB, on one side, and Ireland, on the other, setting out the conditions for the receipt by the latter of financial assistance under the European Financial Stabilisation Mechanism (EFSM). The Court ruled that Directive 77/91/EEC, ${ }^{12}$ which requires, inter alia, any increase in capital in public limited companies to be decided

\footnotetext{
${ }^{8}$ Kotnik (Case C-526/14) ECLI:EU:C:2016:570.

${ }^{9}$ Communication from the Commission on the application, from 1 August 2013, of State aid rules to support measures in favour of banks in the context of the financial crisis [2013] OJ C216/1.

${ }^{10}$ Mallis (Joined Cases C-105/15 P to C-109/15 P) ECLI:EU:C:2016:702.

${ }^{11}$ Dowling (Case C-41/15) ECLI:EU:C:2016:836.

${ }^{12}$ Second Council Directive 77/91/EEC of 13 December 1976 on co-ordination of safeguards which, for the protection of the interests of members and others, are required by member states of companies within the meaning of the second paragraph of Article 58 of the Treaty, in respect of the formation of public limited liability companies and the maintenance and alteration of their capital, with a view to making such safeguards equivalent [1977] OJ L26/1.
} 
upon by the general meeting of shareholders, ${ }^{13}$ does not prevent a measure requiring, among other things, the increase of the share capital of such a company without a general meeting, where such a measure is adopted in the context of a serious disturbance to a member state's economy and financial system which threatens the EU's financial stability.

As it is the most significant of the aforementioned judgments, in terms of contribution to existing jurisprudence and of possible future utilization, the balance of Section I provides a detailed analysis of Ledra Advertising. Before proceeding to discuss the ruling, it is necessary to describe briefly the background to the issues that the Court addressed.

\section{The ESM as a Judicial Protection 'Black Site'}

The euro area states' most enduring response to the currency crisis was the establishment in 2012 of a permanent intergovernmental organization, the ESM, to provide financial assistance to euro area states experiencing severe financing problems. ${ }^{14}$ The ESM is extraordinary for at least two, inter-related, reasons.

Firstly, the ESM exists outside of the formal structures of the Treaty on European Union (TEU), but involves the Commission and ECB in influential roles that the EU Treaties did not envisage for them. These roles include assessing whether financial assistance is necessary where a euro area state requests it, as well as assessing the requesting state's financing needs. ${ }^{15}$ Where financial assistance is to be provided, it is the Commission, in liaison with the ECB, and, where possible, the International Monetary Fund (IMF), that negotiates the MoU,

\footnotetext{
${ }^{13}$ Article 8(1). The contested measure also offended against Articles 25 and 29.

${ }^{14}$ Article 3 ESM.

${ }^{15}$ Article 13(1) ESM.
} 
which sets out the conditions upon which the assistance is granted, with the requesting state on the ESM's behalf. ${ }^{16}$ Moreover, the Commission signs the MoU on the ESM's behalf. ${ }^{17}$ However, all formal decisions are taken by the ESM's Board of Governors, comprising the finance ministers of the euro area states. It is, for instance, the Board of Governors that formally approves the MoU before signature by the Commission on behalf of the ESM. ${ }^{18}$

Secondly, the ESM Treaty closely circumscribes the justiciability of the ESM's activities. While intergovernmental disputes can be ruled upon by the Board of Governors in the first place, ${ }^{19}$ and, ultimately, by the Court of Justice, ${ }^{20}$ the ESM Treaty provides no process through which individuals who have their rights affected may challenge a formal decision of the Board of Governors. Moreover, and this was confirmed in Pringle, the euro area states are not obliged to observe the EU Charter of Fundamental Rights (EUCFR) when conducting ESM activities, since such activities do not involve implementing EU law. ${ }^{21}$ Furthermore, as the ESM Treaty does not confer any decision-making powers on the Commission and ECB, ${ }^{22}$ their ESM activities cannot be challenged by means of an Article 263 TFEU annulment action, with the consequence that the contents of a MoU cannot be set aside judicially. This makes the ESM something of a judicial protection 'black site'. When one considers that the conditions imposed by a MoU may have profound effects on individual citizens' rights, this aspect of the ESM's legal architecture is open to criticism.

\footnotetext{
${ }^{16}$ Article 13(3) ESM.

${ }^{17}$ Article 13(4) ESM.

${ }^{18}$ Article 13(4) ESM.

${ }^{19}$ Article 37(2) ESM.

${ }^{20}$ Article 37(3) ESM.

${ }^{21}$ As required by Article 51(1) EUCFR. See Pringle (Case C-370/12) at paras 179-180.

${ }^{22}$ See Pringle (Case C-370/12) at para. 161.
} 
Despite closing the door to challenges to the Commission and ECB's activities through annulment actions, the Court, in Pringle, did leave open one potential form of redress for individuals whose rights had been adversely affected by the Commission and/or ECB's exercise of their ESM activities. The Court pointed to Article 13(3) and (4) ESM, which require those institutions to ensure that MoUs concluded by the ESM are consistent with EU law. ${ }^{23}$ The implication was that an individual could sue under Article 340 TFEU (noncontractual liability), which requires the EU to make good any damage caused by its institutions when performing their duties. ${ }^{24}$ In 2016, the Grand Chamber, in a number of joined appeals from the General Court, had the opportunity to elaborate on the Commission's ESM Treaty obligations, and, in particular, the extent to which individuals may obtain legal redress for a failure to fulfil these obligations.

Ledra Advertising (Joined Cases C-8/15 P to C-10/15 P)

In Ledra Advertising, the appellants pursued two remedies at first instance. Firstly, they sought to annul a number of paragraphs in the MoU on Specific Economic Policy Conditionality concluded between Cyprus and the ESM of 26 April 2013. This MoU related to the restructuring and resolution of Cyprus Popular Bank (Laïki) and Bank of Cyprus (BoC), the two largest banks in Cyprus, both of which the Commission and ECB had assessed as insolvent. The paragraphs aimed to recapitalize BoC and ensure Laïki's orderly liquidation. Cyprus was required to ensure, inter alia, that the insured deposits of Laiki were taken over by BoC, and that 37.5 per cent of BoC's uninsured deposits be converted into shares with full voting and dividend rights, with another part of those uninsured deposits to

\footnotetext{
${ }^{23}$ Pringle (Case C-370/12) at paras 164 and 174.

${ }^{24}$ Article 268 TFEU confers jurisdiction upon the CJEU to award compensation in non-contractual liability cases.
} 
be temporarily frozen. These obligations were transposed into Cypriot law in March 2013 in advance of the formal conclusion of the MoU. The appellants, all depositors in BoC or Laïki, argued that the value of their deposits had diminished because of the inclusion of the paragraphs, and, as such, the paragraphs amounted to an unjustified interference with their Article 17(1) EUCFR right to property. Secondly, the appellants sought compensation under Article 340 TFEU for this diminution, which they alleged had been incurred due to (a) the inclusion of the paragraphs, and (b) the Commission's failure to ensure before signing it that the MoU was in conformity with EU law, in accordance with its duties as 'guardian of the Treaties' under Article 17(1) TEU and its duty under Article 13(3) and (4) ESM.

Unsurprisingly, both the General Court $^{25}$ and the Grand Chamber refused the first relief. Rejecting the appellants' argument that the Commission and ECB were the real authors of the MoU, and reiterating Pringle, the Grand Chamber ruled that the impugned paragraphs could not be annulled since they were acts of the ESM and, therefore, outside the EU legal order. ${ }^{26}$ However, turning to the appellants' compensation claims, the Grand Chamber disagreed with the General Court, which had ruled that it could not consider actions for compensation based on the paragraphs' alleged illegality. The Grand Chamber, in contrast, held that the Commission's duties under Article 17(1) TEU, and under Article 13(3) and (4) ESM, require it to refrain from signing a MoU whose consistency with EU law it doubts. ${ }^{27}$ Accordingly, the Grand Chamber, setting aside the General Court's orders, ruled that the appellants could, in principle, claim compensation against the Commission for its alleged failure to ensure that

\footnotetext{
${ }^{25}$ Ledra Advertising (Case T-289/13) EU:T:2014:981; Eleftheriou (Case T-291/13) EU:T:2014:978; Theophilou (Case T-293/13) EU:T:2014/979.

${ }^{26}$ At paras 53-54.

${ }^{27}$ At paras 56-60.
} 
the MoU was consistent with Article $17(1)$ EUCFR. ${ }^{28}$ In proceeding to judgment on this question, the Court considered whether the Commission had contributed to a sufficiently serious breach of the appellants' property rights. In this regard, the Court confirmed that the EUCFR binds EU institutions when acting outside of the EU legal framework. ${ }^{29}$ However, in considering whether the Commission had breached the appellants' right to property, the Court, pointing to Article 52(1) EUCFR, observed that restrictions may be imposed on the right so long as they genuinely meet objectives of general interest, do not constitute a disproportionate or intolerable interference with the right, and do not impair the substance of the right. ${ }^{30}$ Referring to Article 12 ESM, which provides that the ESM may offer financial assistance only where 'indispensable to safeguard the financial stability of the euro area as a whole and of its member states', the Court proceeded to find that the adoption of a MoU such as that at issue corresponded to a general interest of the EU. ${ }^{31}$ The Grand Chamber went on to find that the impugned paragraphs did not amount to a disproportionate and intolerable impairing of the very substance of the appellants' right to property. In arriving at this conclusion, the Court considered the central role played by financial services in the EU's economy, and the risk of contagion to banks in the member state concerned or in other member states where one or more banks fail. ${ }^{32}$ The Court also took into account the objective of the measures, and had regard to the imminent risk of financial losses that the appellants would have incurred had Laïki failed. ${ }^{33}$

\section{Assessment}

\footnotetext{
${ }^{28}$ At para. 55.

${ }^{29}$ At para. 67.

${ }^{30}$ At para. 70.

${ }^{31}$ At para. 71.

${ }^{32}$ At para. 72.

${ }^{33}$ At para. 74.
} 
On the issue of judicial protection, the judgment is to be welcomed. The Court has imposed some level of legal accountability on the Commission where it is exercising ESM Treaty activities. It is now clear that the Commission may, in principle, have to compensate individuals where it causes them harm by signing a MoU that is inconsistent with EU law, specifically EUCFR rights. This is certainly preferable to the General Court's conclusion, which would have placed the Commission's activities in negotiating and signing MoUs beyond judicial scrutiny at the behest of individuals. However, the Grand Chamber's assessment of the appellants' claims illustrates the remote chances of success for such claims. The Court's consideration of the impugned paragraphs' proportionality is cursory, and reads like the disposal of a foredoomed claim. The Court shows understandable deference to the Commission and ECB's assessment that the contested measures were necessary to ensure the euro area's stability. However, it is evident that once this general interest is established, the threshold for arguing any interference with property rights is disproportionate will be extremely high. Indeed, having assumed that the objective of the measures was to protect euro area stability, and that the appellants would have been exposed to an imminent risk of losses had Laïki failed, the Grand Chamber did not even proceed to examine the extent of the losses claimed by the appellants. The conclusion must be that the Court will not allow individual property rights to jeopardize the functioning of macro-measures of eurozone crisis management, save where such measures cause an 'intolerable' interference with these rights. Reading between the lines, one suspects that the Court will expect a high level of 'tolerance' from claimants in this regard.

\section{Data Protection}


2016 saw the Union's legislature adopt the General Data Protection Regulation, ${ }^{34}$ which replaces and repeals Directive 95/46/EC. ${ }^{35}$ The new Regulation, adopted along with Directive $2016 / 680 / \mathrm{EU}^{36}{ }^{36}$ which governs procedures for the processing of data by competent national authorities in criminal matters, will apply from 25 May $2018 .{ }^{37}$ Elsewhere, the EU and USA, in reaction to the Grand Chamber's 2015 judgment in Schrems, ${ }^{38}$ concluded a new agreement on data transfer between the EU and USA for criminal law enforcement purposes. It will be recalled that Decision 2000/520, ${ }^{39}$ which had previously regulated data transfers between the parties to the agreement, was invalidated in Schrems. The new agreement entered into force on 1 February $2017 .{ }^{40}$ Moreover, the Grand Chamber gave its ruling in the joined cases Tele 2 Sverige and Watson, thereby providing an important clarification of Digital Rights Ireland, ${ }^{41}$ one of the Court's most significant rulings in recent times. This contribution now turns to assess Tele2 Sverige.

\footnotetext{
${ }^{34}$ Regulation 2016/679/EU of the European Parliament and of the Council of 27 April 2016 on the protection of natural persons with regard to the processing of personal data and on the free movement of such data [2016] OJ L119/1.

${ }^{35}$ Directive 95/46/EC of the European Parliament and of the Council of 24 October 1995 on the protection of individuals with regard to the processing of personal data and on the free movement of such data [1995] OJ L281/31.

${ }^{36}$ Directive (EU) 2016/680 of the European Parliament and of the Council of 27 April 2016 on the protection of natural persons with regard to the processing of personal data by competent authorities for the purposes of the prevention, investigation, detection or prosecution of criminal offences or the execution of criminal penalties, and on the free movement of such data [2016] OJ L119/89.

${ }^{37}$ Article 99(2).

${ }^{38}$ Schrems (Case C-362/14) ECLI:EU:C:2015:650.

39 2000/520/EC: Commission Decision of 26 July 2000 pursuant to Directive 95/46/EC of the European Parliament and of the Council on the adequacy of the protection provided by the safe harbour privacy principles and related frequently asked questions issued by the US Department of Commerce [2000] OJ L215/7.

${ }^{40}$ Information concerning the entry into force of the Agreement between the United States of America and the European Union on the protection of personal information relating to the prevention, investigation, detection, and prosecution of criminal offences [2017] OJ L25/1.

${ }^{41}$ Digital Rights Ireland (Case C-293/12) ECLI:EU:C:2014:238.
} 
In 2014, in Digital Rights Ireland, the Grand Chamber invalidated Directive 2006/24/EC, ${ }^{42}$ ruling it an unjustifiable interference with Articles 7 and 8 EUCFR, the rights to privacy and the protection of personal data, respectively (Horsley, 2015, pp. 113-116). Directive 2006/24/EC, adopted after the 2005 London bombings, had required member states to introduce laws compelling telecommunications operators to retain specific categories of data generated and processed by them for periods not less than six months and not more than two years from the date of the communication, ${ }^{43}$ and to allow competent national authorities to access such data. ${ }^{44}$ When Digital Rights Ireland sealed the Directive's fate, one might have imagined that national measures transposing its obligations were endangered. However, disagreement arose subsequently at national level as to whether the ruling constituted a total prohibition on measures imposing general and indiscriminate obligations on telecommunications operators to retain electronic communications data. Those arguing that the ruling did not constitute such an injunction relied upon Article 15(1) of Directive 2002/58. ${ }^{45}$ This provision permits member states to adopt legislative measures to restrict the scope of rights under that Directive, including the right to confidentiality of communications, ${ }^{46}$ where necessary to safeguard, inter alia, national security, defence, public security, and the prevention, investigation, detection and prosecution of criminal offences.

\footnotetext{
${ }^{42}$ Directive 2006/24/EC of the European Parliament and of the Council of 15 March 2006 on the retention of data generated or processed in connection with the provision of publicly available electronic communications services or of public communications networks [2006] OJ L105/54.

${ }^{43}$ Articles 3, 5 and 6.

${ }^{44}$ Article 4.

${ }^{45}$ Directive 2002/58/EC of the European Parliament and of the Council of 12 July 2002 concerning the processing of personal data and the protection of privacy in the electronic communications sector [2002] OJ L201/37.

${ }^{46}$ Article 5(1).
} 
Moreover, Article 15(1) specifically permits member states to adopt measures providing for data retention for a limited period justified on the aforementioned grounds.

The joined cases of Tele2 Sverige and Watson arose from challenges before the Administrative Court of Appeal, Stockholm and the Court of Appeal of England \& Wales, respectively as to the validity of national legislation transposing the defunct Directive. The Grand Chamber provided rulings on two questions. ${ }^{47}$ First, whether Article 15(1) of Directive 2002/58/EC, read together with Articles 7, 8 and Article 52(1) EUCFR, precludes national legislation, which for the purposes of fighting crime, provides for a general and indiscriminate data retention obligation. Second, whether the same EU law provisions preclude national legislation requiring access by competent national authorities to retained data (i) where access is not restricted to the objective of fighting serious crime, (ii) where access is not subject to prior judicial or independent administrative review, and (iii) where there is no requirement that the data concerned should be retained within the EU.

Before considering either question, the Grand Chamber dealt with the issue of whether the national legislation fell within the scope of EU law, in particular Directive 2002/58/EC. ${ }^{48}$ The UK government had argued that the Directive applied to legislation obligating retention of data, but not access to it. The Court dismissed this argument, holding that the Directive applies to national provisions relating to both requirements. ${ }^{49}$ The Grand Chamber justified this by pointing to Article 5(1) of the Directive, which protects confidentiality of electronic communications, and Recital 21, which states that the Directive's aim is to prevent

\footnotetext{
${ }^{47}$ A third question, whether Digital Rights Ireland had interpreted Articles 7 and/or 8 EUCFR in such a way as to expand the scope of Article 8 of the European Convention on Human Rights (ECHR), was hypothetical, and, therefore, inadmissible (at paras 126-133).

${ }^{48}$ At paras 65-81.

${ }^{49}$ At para. 76.
} 
unauthorized access to such data to protect confidentiality. ${ }^{50}$ The Court stated further that there is an inextricable link between retention and access, since national legislation imposing data retention obligations presupposes the existence of provisions relating to access by competent national authorities. ${ }^{51}$

Moving to the substance of the first question, the Court emphasized that Article 15(1) permits member states to derogate from the principle of data confidentiality and should, therefore, be interpreted strictly. ${ }^{52}$ The Grand Chamber stated that the list of objectives in Article 15(1) permitting derogation from the principle of confidentiality is exhaustive, and any measure enacted further to the provision must be interpreted in light of EUCFR rights. ${ }^{53}$ The obligations imposed by the national legislation at issue, the Court continued, raised questions as to compatibility with not only Articles 7 and 8, but also Article 11 EUCFR (freedom of expression). ${ }^{54}$ Turning to the issue of whether retention obligations of the kind in the impugned national legislation constituted a proportionate interference with Articles 7 and 8, the Grand Chamber regarded the interference resulting from the retention obligations to be 'very far-reaching and ... particularly serious'. ${ }^{55}$ In this regard, the Court pointed to the nature of the data to be retained, which made it possible to identify, inter alia, the date, time, duration and type of communication. ${ }^{56}$ This information would allow "very precise conclusions to be drawn concerning the private lives of the persons whose data has been retained' ${ }^{57}$ Given the seriousness of the interference, only the objective of fighting serious

\footnotetext{
${ }^{50}$ At para. 77.

${ }^{51}$ At para. 78.

${ }^{52}$ At para. 89.

${ }^{53}$ At para. 91.

${ }^{54}$ At para. 92.

${ }^{55}$ At para. 100.

${ }^{56}$ At para. 98.

${ }^{57}$ At para. 99.
} 
crime could justify a requirement for the retention of traffic and location data. ${ }^{58}$ However, this objective could not itself justify national legislation providing for general and indiscriminate retention. ${ }^{59}$ The Court provided two reasons for this. First, such legislation makes data retention the rule, whereas Directive 2002/58/EC requires retention to be exceptional. ${ }^{60}$ Second, such legislation, being comprehensive, and not allowing for any differentiation, limitation or exception in light of the objective pursued, affects all persons using electronic communications services, even where there exists no evidence linking such persons to serious criminality. ${ }^{61}$

The Court then proceeded to provide some much-needed guidance as to when national legislation might be compatible with EU law. It confirmed that member states could, as a preventative measure, for the purpose of fighting serious crime, adopt legislation permitting the 'targeted retention of traffic and location data'. ${ }^{62}$ However, such retention would have to be 'limited, with respect to the categories of data to be retained, the means of communication affected, the persons concerned and the retention period adopted, to what is strictly necessary ${ }^{63}$ The Grand Chamber identified two conditions that would have to be met. First, any national legislation would have to set clear and precise rules concerning the scope and application of such data retention and impose minimum safeguards, so that persons whose data have been retained have sufficient guarantees of the effective protection of their personal

\footnotetext{
${ }^{58}$ At para. 102.

${ }^{59}$ At para. 103.

${ }^{60}$ At para. 104.

${ }^{61}$ At para. 105.

${ }^{62}$ At para. 108.

${ }^{63}$ At para. 108.
} 
data from the risk of misuse. ${ }^{64}$ Secondly, any national measures would have to meet objective criteria that establish a link between the data to be retained and the objective pursued. ${ }^{65}$

The Grand Chamber's ruling on the second question relating to access by national competent authorities to retained data followed similar reasoning. Where national measures allowing access by national competent authorities to retained data were designed to combat crime, such measures would only be regarded as strictly necessary where access is restricted to 'the data of individuals suspected of planning, committing or having committed a serious crime ...' ${ }^{66}$ However, the Grand Chamber did concede that access to other persons' data might be permissible where, for example, vital national security, defence or public security interests were threatened by terrorism. In such situations, however, there would have to be 'objective evidence from which it can be deduced that the data might, in a specific case, make an effective contribution to combating such activities' ${ }^{67}$ The Grand Chamber then proceeded to establish a number of procedural protections that national legislation should contain. Most significantly, the Court stated that, save in cases of validly established urgency, access of national competent authorities to retained data should be subject to prior review by a court or independent administrative body. ${ }^{68}$

\section{Assessment}

No case encapsulates the EU's year, legal and otherwise, quite like Tele2 Sverige. Delivered two days after the Berlin Christmas market attack, the judgment sees the Grand Chamber

\footnotetext{
${ }^{64}$ At para. 109.

${ }^{65}$ At para. 110.

${ }^{66}$ At para. 119.

${ }^{67}$ At para. 119.

${ }^{68}$ At para. 120.
} 
seeking to balance two competing interests: on one hand, the prevention of terrorism and serious crime and, on the other, the protection of privacy rights. The ruling continues the approach in Digital Rights Ireland, one characterized by an aversion to general and indiscriminate interference with privacy rights, even in the face of the very real threat of terrorism in contemporary Europe. One may laud the Court for its robust protection of individual rights (Scheinin, 2016), or accuse it of hamstringing security services' ability to combat terrorism (Epstein, 2016). Whatever one's views, the Court's approach is in stark contrast to that taken to the balancing of individual rights against the general interest of ensuring euro area stability. Whereas in Ledra Advertising the Grand Chamber was deferential to the EU institutions and required the appellants to demonstrate an intolerable interference with their property rights, in Tele2 Sverige the onus was heavily on the member states to demonstrate that the interferences with individual rights were strictly necessary. Another notable aspect of the judgment is the confirmation that national measures relating to access to retained personal data by competent national authorities fall within the scope of Directive 2002/58/EC. While one might see this as an example of 'competence creep', the Grand Chamber's argument that the retention of, and access to, data are inextricably linked is convincing. The judgment also provides much-needed guidance to member states as to the matters they need to consider when legislating in this area, and, in this regard, clarifies the judgment in Digital Rights Ireland significantly.

The ruling's significance in the UK context deserves comment also. In Watson, the applicants, including MPs Tom Watson and David Davis, sought to review the legality of a provision of an Act of Parliament by arguing its incompatibility with EU law. A significant issue in the debate preceding the Brexit referendum was Parliamentary sovereignty, a British constitutional concept that holds that whatever the Queen in Parliament enacts is the law, and 
that no other body may question that law's validity. EU law's supremacy in the UK, given effect by the European Communities Act 1972, however, has empowered British courts to protect EU law rights from Parliamentary interference. It is indeed ironic that a case commenced by Mr Davis, arch eurosceptic and now Secretary of State for Exiting the EU, serves as a reminder of the important role the CJEU and EU law have played in the UK in providing judicial protection of rights against legislative interference, a role they almost certainly will not enjoy after Brexit. The judgment also has a more prosaic significance. Less than a month before the ruling, Westminster enacted the Investigatory Powers Act 2016, Section 87 of which contains the type of general and indiscriminate data retention powers condemned in Tele2 Sverige. The commencement of most of Section 87 eight days after the judgment may foreshadow a decreasing authority of EU law in the UK following the triggering of Article 50 TEU.

\section{EU Citizenship Rights}

Against a backdrop of increasing debate in many member states about the economic and social consequences of both EU and non-EU migration, the Court of Justice in 2016 delivered a number of important judgments on EU citizenship rights. A theme evident in the Court's recent jurisprudence has been a deceleration of its initial expansive development of EU citizenship, which was based on Article 20 TFEU as an autonomous source of citizenship rights. ${ }^{69}$

The deceleration has manifested itself in various ways. The Court has, in a manner suggestive of sensitivity to member state concerns about 'benefits tourism', taken a more restrictive

${ }_{69}$ See, for example, Grzelczyk (Case C-184/99) ECLI:EU:C:2001:458; Baumbast (Case C-413/99) ECLI:EU:C:2002:493. 
approach to the citizenship rights of non-economically active EU citizens, most notably in Dano. ${ }^{70}$ This has been accompanied by more infrequent utilization of Article 20 TFEU as an autonomous source of EU citizenship rights, and greater reliance on more restrictive EU secondary law, specifically Directive $2004 / 38 / \mathrm{EC},{ }^{71}$ to define the boundaries of citizenship rights. Similarly, the Court has toned down its once effusive rhetoric on EU citizenship: gone are the references to EU citizenship as 'destined to be the fundamental status of nationals of the member states'. ${ }^{72}$

Furthermore, where the Court has used Article 20 TFEU to make, from the member states' viewpoint, incursions into areas traditionally understood as matters of purely national migration policy ('wholly internal situations'), it has moved, possibly in response to member state concerns, to tightly limit the circumstances in which such 'incursions' occur. This phenomenon was evident after Zambrano. ${ }^{73}$ In that case, the Court ruled that a member state may not refuse residence to the third-country primary carer of a dependent EU-citizen child, where such refusal would lead to the carer's removal from the territory of the EU and, by extension, also the child's removal. This is the case, even where the child was born and had lived his/her entire life in one member state, and had therefore never exercised free movement rights. The Court reasoned that the carer's removal in such circumstances would have the effect of depriving the EU-citizen child of the substance of his/her Article 20 TFEU

\footnotetext{
${ }^{70}$ Dano (Case C-333/13) ECLI:EU:C:2014:2358.

${ }^{71}$ Directive 2004/38/EC of the European Parliament and of the Council of 29 April 2004 on the right of citizens of the Union and their family members to move and reside freely within the territory of the member states [2004] OJ L158/77.

${ }^{72}$ See, for example, Grzelczyk (Case C-184/99) at para. 31.

${ }^{73}$ Zambrano (Case C-34/09) ECLI:EU:C:2011:124.
} 
citizenship rights. Thereafter followed a number of judgments in which the Court sought to limit the ruling's effect. ${ }^{74}$

The trend described above, with its various manifestations, was observable in the Court's decision-making concerning EU citizenship rights in 2016.

In Commission v United Kingdom, ${ }^{75}$ the First Chamber ruled that UK legislation requiring a claimant for child benefit or child tax credit to have a UK right of residence does not contravene Article 4 of Regulation 883/2004/EC. ${ }^{76}$ Article 4, when read with Article 11(1) and (3), provides that EU citizens who are resident in another member state must enjoy the same benefits under national legislation as citizens of the host State. The Commission had argued that 'residency' in the context of Regulation 883/2004/EC has an autonomous meaning, unconnected with any national law definition or, indeed, any right of residence under Directive 2004/38/EC. As such, the Commission maintained that the UK had imposed a condition that was not present in the Regulation or, in the alternative, was directly discriminatory against non-UK EU citizens. The judgment, delivered just over a week before the Brexit referendum, was perceived by some as the EU judiciary's response to UK government concerns about 'benefits tourism' and the British public's mood on the subject (O’Brien, 2017).

\footnotetext{
74 See, for example, McCarthy (Case C-434/09) ECLI:EU:C:2011:277; Dereci (Case C-256/11) ECLI:EU:C:2011:734; Alokpa (Case C-86/12) ECLI:EU:C:2013:645.

${ }^{75}$ Commission v United Kingdom (Case C-308/14) ECLI:EU:C:2016:436.

${ }^{76}$ Regulation 883/2004/EC of the European Parliament and of the Council of 29 April 2004 on the co-ordination of social security systems.
} 
The Court's move to contain Zambrano also continued. In $C S,{ }^{77}$ the Grand Chamber ruled, again in agreement with the UK, that Article 20 TFEU, as interpreted in Zambrano, does not constitute an absolute prohibition on member states expelling a third-country national primary carer of a young EU-citizen child, even where such removal would lead to the carer and child having to leave the territory of the EU. However, the Court did retain the Zambrano rationale as the general rule, emphasizing that expulsion in such a situation would only be permissible under EU law in exceptional circumstances. ${ }^{78}$ In particular, the Grand Chamber stated that any expulsion measure would have to be based on 'the personal conduct of [the] third-country national, which must constitute a genuine, present and sufficiently serious threat adversely affecting one of the fundamental interests of the society of that Member State, and $\ldots$ on consideration of the various interests involved' ${ }^{79}$ In making this determination, a national court would also have to take account of the right to respect for private and family life under Article 7 EUCFR and the best interests of the child, and to ensure that the proportionality principle is observed. ${ }^{80}$ It is noteworthy that although Directive 2004/38/EC did not apply in CS, since the British-citizen child had never exercised EU free movement rights, the Court, in determining the extent of the child's EU citizenship rights, relied on previous rulings related to restrictions to free movement under the Directive and its predecessors.

In another ruling delivered on the same day, the Grand Chamber, in Rendón Marín, ${ }^{81}$ reaffirmed the general rule in Zambrano. Rendón Marín, a Colombian national living in Spain, had been refused a residence permit due to a Spanish law that required automatic

\footnotetext{
${ }^{77}$ CS (Case C-304/14) ECLI:EU:C:2016:674.

${ }^{78}$ At para. 50.

${ }^{79}$ At para. 50.

${ }^{80}$ At paras 48 and 49.

${ }^{81}$ Rendón Marín (Case C-165/14) ECLI:EU:C:2016:675.
} 
refusal where an applicant had a criminal record. Rendón Marín was the father and sole carer of two EU-citizen children, both of whom had been born and had lived their entire lives in Spain. Rendón Marín's daughter was a dual Spanish/Polish citizen, which meant, following Zhu and Chen, ${ }^{82}$ that she could rely on Article 21 TFEU and Directive 2004/38/EC, since her situation was not 'wholly internal'. However, Rendón Marín's son was a Spanish citizen only, meaning that he could not rely upon those provisions, as he had never exercised his free movement rights. As such, in the context of his son, Rendón Marín had to rely on Article 20 TFEU and Zambrano. In its reply to the Spanish Tribunal Supremo, the Grand Chamber ruled that Article 21 TFEU and Directive 2004/38/EC preclude national legislation that requires that a third-county national, in Rendón Marín's familial circumstances, be automatically refused residency solely because he/she has a criminal record. ${ }^{83}$ Furthermore, the Court ruled that Article 20 TFEU prohibits such legislation, where refusal results in an EU-citizen child having to leave EU territory. ${ }^{84}$ However, the Court, affirming its ruling in Alokpa ${ }^{85}$, added that Rendón Marín's son's Article 20 TFEU rights would not be contravened if the family could lawfully reside in Poland due to his sister's dual nationality, since removal from Spain would not result in removal from EU territory. ${ }^{86}$ This question, according to the Court of Justice, was for the national court to determine on consideration of the facts. ${ }^{87}$ It is an aspect of the ruling that may result in much hardship and uncertainty.

It is difficult to say with certainty what is driving the Luxembourg Court's circumspection in the area of EU citizenship rights. The Court's collegiate judgments can be deductive and the

\footnotetext{
${ }^{82}$ Zhu and Chen (Case C-200/02) ECLI:EU:C:2004:639.

${ }^{83}$ At para. 88.

${ }^{84}$ At para. 88.

${ }^{85}$ Alokpa (Case C-86/12) ECLI:EU:C:2013:645.

${ }^{86}$ At para. 79.

${ }^{87}$ At para. 79.
} 
result of compromise, making it often difficult to identify factors motivating them. An intergovernmentalist convinced that the CJEU is largely controlled by the preferences of powerful member state governments might find succour in the recent citizenship rulings. However, such analysis conflates control and influence. The Court's current President, Koen Lenaerts, writing extrajudicially, has stated that the Court seeks 'to strike the balance imposed by the rule of law among the different interests at stake in a multilayer system of governance' (Lenaerts, 2013, p. 1304). There is, accordingly, nothing unusual or improper in the Court being responsive to member state government concerns where expressed through legal submissions. One may also assert that while there has been a slow-down in the Court's development of EU citizenship rights, the Court has not gone into full retreat. Lenaerts has also commented on the Court's 'stone-by-stone' approach to doctrine development (Lenaerts, 2013, p. 1351). This functional approach, which echoes that of the EU's founding fathers, might involve recognition that 'Rome wasn't built in a day', and that in the contemporary climate, if EU citizenship is 'destined to be the fundamental status of nationals of the member states', the Court may have to tread slowly and carefully. Whether the Court of Justice will continue with this patient development of EU citizenship rights in the coming years is an open question. One could characterize the Court's approach in cases like Commission $v$ United Kingdom as a policy of appeasement. If the Court has adopted such a policy, it has either not worked or it has come too late, for a slim majority of the UK's electorate at least.

\section{Concluding Remarks}

The CJEU is no longer ' $[\mathrm{t}]$ ucked away in the fairyland Duchy of Luxembourg and blessed ... with benign neglect' (Stein, 1981, p. 1). The EU judiciary's role and decisions have come under increasing scrutiny and criticism in recent years. The expansion of the EU's 
competences, and the political response to the eurozone crisis, has required the CJEU to adjudicate on matters of increasing controversy. 2016 saw a cluster of challenges to European integration: the legacy of the eurozone crisis, the ongoing migrant crisis, terrorism, and the threat of further disintegration following the UK referendum. ${ }^{88}$ The foregoing survey of the Grand Chamber's activities in the past year has shown the Court attempting to wrestle with many of these issues. Variances in how the Court has addressed different challenges within the three areas surveyed have emerged. In the areas of eurozone crisis management and EU citizenship rights, the Court has demonstrated deference to the EU's institutions and member states, respectively. In the context of the threat of terrorism, the Court has faced down member state legislatures, having previously done so to the EU legislature in Digital Rights Ireland, to protect privacy rights robustly. In the main, however, the survey illustrates that the Grand Chamber has continued to develop further the groundwork it laid in seminal decisions like Pringle, Digital Rights Ireland and Zambrano. As such, 2016 was a year of doctrinal continuity and consolidation, rather than one involving the breaking of any particularly novel ground. One might say that in the eye of the storm, the Court has, in stereotypically British manner, kept calm and carried on. Against this, one might argue that 2016 was the calm before the storm, rather than its eye, and that the most significant challenges posed by the spectre of disintegration have yet to come.

\section{References}

Amtenbrink, F. (2013) ‘Legal Developments’, JCMS, Vol. 51 No. s1, pp. 139-154.

Epstein, R.A. (2016) 'The ECJ's Fatal Imbalance: Its Cavalier Treatment of National

Security Issues Poses Serious Risk to Public Safety and Sound Commercial Practices'. European Constitutional Law Review, Vol. 12, No. 2, pp. 330-340.

\footnotetext{
${ }^{88}$ See the other contributions to this volume.
} 
Horsley, T. (2015) “"The Court Hereby Rules ...” - Legal Developments in EU Fundamental Rights Protection', JCMS, Vol. 53 No. s1, pp. 108-127.

Horsley, T. (2016) 'Eurozone Crisis Management, Citizenship Rights and the Global Reach of EU Data Protection Law: EU Legal Developments in 2015', JCMS, Vol. 54 No. s1, pp. $117-133$.

Lenaerts, K. (2013) 'How the ECJ Thinks: A Study on Judicial Legitimacy'. Fordham International Law Journal, Vol. 36, No. 5, pp. 1302-1371.

O’Brien, C. (2017) 'Court of Justice The ECJ sacrifices EU citizenship in vain: Commission v. United Kingdom'. Common Market Law Review, Vol. 54, No. 1, pp. 209-243.

Scheinin, M. (2016) 'Towards Evidence-Based Discussion on Surveillance: A Rejoinder to Richard A. Epstein'. European Constitutional Law Review, Vol. 12, No. 2, pp. 341-348.

Stein, E. (1981) 'Lawyers, Judges, and the Making of a Transnational Constitution'. American Journal of International Law, Vol. 75, No. 1, pp. 1-27. 